\title{
JEWISH AVERROISTS BETWEEN TWO EXPULSIONS (1306-1492): FROM CONFLICT TO RECONCILIATION
}

\author{
Basem Mahmud \\ Freie Universität Berlin
}

\begin{abstract}
This article investigates the intellectual production of Jewish authors influenced by Averroes in the $14^{\text {th }}$ and $15^{\text {th }}$ Centuries in northern Spain and southern France. The primary objective is to determine the main features of Jewish Averroism in this period, and to understand it within its socio-historical context. The outcomes suggest that there was a relationship between the new social and political trends toward democratization and reconciliation in the heart of Jewish communities on one hand, and the growing interest in Averroes' original works on the other. Original here means the works that are not commentaries or summaries of other works.
\end{abstract}

Key words: Aristotelianism, Averroes, Averroism, Jewish philosophy, Kabbalah, Maimonides, Scripture.

\section{INTRODUCTION}

«There is nothing worse in social government than a policy that makes one single society into several, just as there is no greater good in communities than a policy that joins and unifies» (Averroes) ${ }^{l}$

The $14^{\text {th }}$ Century was a very difficult time for Jewish communities in northern Spain and southern France, they faced great threats from outside as well as significant domestic division. The domestic conflict emerged not only because of religious and philosophical issues, but also due to economic and social matters related to the distribution of wealth and power within Jewish communities. ${ }^{2}$ In addition, these communities lived in delicate conditions due to threats from the Christians. This situation also had an effect on demographics. Since the last years of $13^{\text {th }}$ Century, the Jewish community started to encounter sizeable obstacles in its demographic development. ${ }^{3}$ Under these conditions, Hebraic Averroism continued its development which had begun in XIII century.

Since the appearance of Renan's book (Averroes et L'Averroisme) in 1861, many researchers have followed him, focusing on the role of Jewish intellectuals in the conservation

1 Averroes, Exposición de la República de Platón, Trad. Cruz Hernández, M., Madrid, 2011, p. 64.

2 For example, in 1370 in Mallorca a wealthy and powerful minority that exercised control over 500 families is accused of being Averroist and agnostic (Hinojosa Montalvo, J., «La sociedad y la economía de los judíos en Castilla y la Corona de Aragón durante la baja edad media», in II Semana de Estudios Medievales : Nájera, 5 al 9 de agosto de 1991, De La Iglesia Duarte, J. (coord.), Logroño, Instituto de Estudios Riojanos, 1992, pp. 88-89).

3 For example, in Zaragoza the Jewish population was reduced by $1 / 5$. The Jewish quarters were attacked by Christians and the attacks in 1391 resulted in the death and fleeing of many Jews (Hinojosa Montalvo, J., «La sociedad y la economía», p. 82). 
and transition of Averroes' works, and therefore Aristotelianism to Europe. Few scholars studied the interaction between the religious and philosophical output of these intellectuals on one hand and the socio-political context on the other. How did Averroist intellectuals experience this process of momentous changes in the political, social, economic and demographic structures that they were witnessing with their own eyes? How was it reflected in their works?

During the $14^{\text {th }}$ Century, within the economic and social field, there was a trend toward democratization. This can be observed through the changes that occurred in the tax system in many Aljamas (Jewish communities), combining the direct and indirect taxes and introducing the Sisas system. ${ }^{4}$ According to the tax system, the Jewish community was divided into:

The non-taxpayers (francos), who were a minority that belonged to the upper class. They had the privilege of not paying taxes, and state officials could not enter their property without their consent; «the existence of these franco Jews was a burden for the rest, who had to pay taxes of the Aljama and this was the cause of great tension in the Jewish quarter.» ${ }^{5}$ These Jews tended to enjoy a high cultural level and «libraries not lacking the works of Ptolemy, Nahmanides and Averroes..${ }^{6}$

The taxpayers (pecheros) are divided into three groups; upper, middle and lower. The last group is the most economically destitute. The upper class is the aristocracy. They had deep philosophical knowledge, as demonstrated by their libraries. ${ }^{7}$ The middle class was made up of people that were dedicated to artisanal or factory work, commerce and other professions that had an ample social base. ${ }^{8}$ In general, Jews that belonged to the upper class and a significant part of the middle classes defended Maimonides, because this school of thought allowed them to continue to carry out their commercial and economic activities and therefore conserve their status. ${ }^{9}$

4 Hinojosa Montalvo, J., «La sociedad y la economía», pp. 79-110.

5 Muñez Jiménez, I., «Juderías de realengo y juderías de señorío: la judería de Calatayud», en Juderías y Sinagogas de la Sefarad Medieval: en memorial de José Luis Lacave Riaño : XI Curso de Cultura Hispano, López Alvarez, A \& Izquierdo Benito, R. (coord.), Castilla-La Mancha, Universidad de Castilla-La Mancha, 2003, 159-199: 178.

6 Hinojosa Montalvo, J., «La sociedad y la economía», p. 86.

7 The National Library has several manuscripts from the Jewish community in Catalayud, Spain, including Averroes' Commentary on Aristotle's Metaphysics in the translation of Qalonymos b. Qalonymos, written by Juda Gagonia for personal use. Dated 5229 after the creation of the world [1469 of the Christian Era], cf. Sirat, C. \& BET ARIE, M., Manuscrits Médiévaux en caractéres hébraiques portant des indications de date jusqu'a 1540, Jerusalem, Centre Nationale des Sciences et des Lettres d'Israel, Vol. I, 51 and 137; vol. II, 102, and vol. III, 10. [Original not consulted, cited by Motis Dolader, M. Á., «Judios y conversos en la Raya Occidental del Reino de Aragón (siglos XII-XV)», Zaragoza, the Institución Fernando el Católico, Borja y la raya occidental de Aragón, 1992, p. 125.

8 Motis Dolader, M. Á., «La sociedad judía aragonesa en la Edad Media», Historia de Aragón, II. Economía y Sociedad, Institución Fernando el Católico, 1996, pp. 345-362: 353

9 «The upper classes subscribed to Maimonides' doctrine that permitted them to interact with Christians, provided them tax exemptions in their contribution to the aljama, but also led them to corruption and lax religious practice, which was looked down upon by the humble class.» (Hinojosa Montalvo, J., «La sociedad y la economía», p. 85). Something similar happened during the development of what Arkoun calls «Arab humanism». (cf. Arkoun, M., Naz 'at al-ansana fì al-fikr al- 'arabī [The humanist trend in Arab thought], London, 1997). This humanism represents an open mentality to all knowledge, a mentality that is interested in humankind. The development came in parallel with the development of the cities in which new more complex means of administration and the economic and commercial relations are needed. In these new cities «a new active commercial and capitalist middle class appeared». (Cf. AL-Dūriyyu, 'A. A., Muqaddima fì al-tarīh aliqtiṣādi al- 'arabī [introduction to Arab economic history], Beirut, 1987, p. 72). Changes in the socio-economic 
In a previous article, I concentrated on the $13^{\text {th }}$ century and demonstrated how what I call «the first Averroist generation of Jewish intellectuals» used Averroes' commentary on Aristotle to combat mysticism without having paid much attention to his original works ${ }^{10}$. In this article, I will follow the circulation of the works produced by their successors. Did they continue reading and employing Averroes/Maimonides' works for the same purposes and in the same way? If the answer is no, then what were the most prominent changes? These are the questions I will address in the following lines. Before going into details about these intellectuals and the socio-political context of their time, it is necessary to explain the two main kinds of Averroes' works; original and commentary.

\section{AVERROES' ORIGINAL WORKS}

The Jews translated Averroes' commentary on Aristotle's works, taking Maimonides' advice when he said: «Aristotle's books are the root and foundation of all current scientific books; but they are not understood by themselves, unless accompanied by their commentaries, the commentary of Alexander of Aphrodisias, Themistius, and Averroes' commentary». ${ }^{11}$ His original works were also translated, namely, the works that are not commentaries or summaries of other works, they are the following:

1. Faṣl al-maqāl fì taqrīr mā-bayn al-šarī'a wa al-hikma min al-ittișāl (Decisive doctrine about the concordance between revelation and wisdom): the translation dates between the late $13^{\text {th }}$ Century and the early $14^{\text {th }}$ Century, and was published by Golb. ${ }^{12}$

2. Damima li-mas 'alat al- 'ilm al-qadìm (Letter to a friend about the science of God $)^{13}$ : Vajda, G., found two Hebrew translations, ${ }^{14}$ one by Ṭodros ben Měšullām ben David, also known as Todros Țodrosi, which was completed around 1337. The second translation was completed in 1472, although the author is unknown.

3. Tahäfut al-tahāfut (Incoherence of the Incoherence): translated by Qalōnymūs b. David b. Todros, completed in 1328 with the title Happalat ha-Happalah. There is

structure brought about changes in thought and literature including Fiqh. During the economic development in the era of the Abbasids from the 14th Century - as Islam prohibited certain forms of economic exchange- at this time, the books of chicanery appeared (hiyal), like the book, al-Ğāḥiz, al-Tabașsur bi al-tiğāra [The prospective strategy of commerce, the books of al-Š̉aybānī, al-'Iktisāa fi al-rizq [The acquisition of the means of life] and al-Mahāriğ wa al- hiyal [Exits and chicanery]. The book by al-Dimašqī, al-'Išāra ilà mahāasin al-tiğāra [The reference of the advantages of commerce]. These books attempt to resolve all obstacles faced by men dedicated to commercial activities. (Cf. AL-Dūriyyu, 'A. A., Muqaddima fì al-tarīh, p. 71).

10 Mahmud, B., «El averroismo hebraico en los reinos cristianos: Desde el exilio hasta la expulsión del Reino de Francia», Revista Española de Filosofia Medieval, 23 (2016), pp. 189-203

11 Letter from Maimónides to Ibn Tibbón, cf. Maimónides, Cinco epistolas de Maimónides, introducción, traducción y notas by José Cano, M \& Ferre, D., Barcelona, Riopedras Ediciones, 1988, pp. 121-122.

12 Golb, N., «The Hebrew Translation of Averroes' "Fașl al-Maqāl"», Proceedings of the American Academy for Jewish Research, 25, 1956, pp. 91- 113 y 26, 1957, pp. 41-46.

13 Name comes from Damīma, which means to include. It is because it was included in Faṣl al-maqāl, because Averroes refers to it at the start of his book.

14 Vajda, G., «Les deux versions hébraïques de la dissertationd'Averroès sur la science divine », Revue des études juives, 113, 1954, 63-66. [Work not consulted, cited by Nasri Nader, A. Faṣl al-maqāl, Beirut, Dar al-Mashriq, 1968.] 
another translation by an unknown translator with the title Sĕfer ha-Tekumah. It is the translation used by Mošeh Narbōnī. ${ }^{15}$

4. Al-Kulliyyāt fi al- tib (The Generalities of Medicine): the most famous translations of this book are the following versions: the first completed by Sulaymān b. Ibrahim b. Dāūd, in the early $14^{\text {th }}$ Century, and another version, which according to Moritz Steinschneider is from an unknown translator, but according to Suessmann Muntener it is Moisés ben Tibbón (translator of Aurjōza). Steinschneider says that the date of translation is also unknown. However, Suessmann Muntner later published a different article in Hebrew (Kirjat Sepher XXIII, 1946, 62-72) where he changes his previous opinion and says that the translator is Ya'qōb b. Qațan. As the translation was carried out at the request of Maimonides, the date must be before 1204 (the year of Maimonides death) or shortly thereafter. ${ }^{16}$

5. Al-kašf' an manāhiğ al-adilla fì 'aqā'id al-milla (Exposition of the Methods of Proof Concerning the Beliefs of the Community): anonymous translator, according to $\mathrm{M}$. Steinchneider, the date must be after the second half of the $14^{\text {th }}$ Century or shortly before. ${ }^{17}$

Furthermore, we must pay special attention to Averroes' Commentary on Plato's Republic because it reflects his political agenda. This book was likely written at the request of Abu Yahyà (brother of al-Manșūr), around the time he was trying to seize political control by taking advantage of al- Manșūr's illness in $1191 .^{18}$ In this work, Averroes comments on Plato from an Aristotelian position. His commentary omits some parts of the original text, and instead incorporates references to Aristotle. The most important part of the commentary are his own reflections in which he engages with the original text in a way that makes it relevant to the society and political climate in which he lived in Al-Andalus. These reflections account for a third of the commentary as a whole. ${ }^{19}$

\section{JEWISH AVERROISTS}

During the $14^{\text {th }}$ Century, new translations were carried out. The social context where the Jews lived had changed. The persecutions and threats from Christians were intensifying. The Maimonidean Controversy represented a dramatic domestic division as mentioned previously. Jewish intellectuals were concerned for the unity and cohesion of the Jewish community. To understand the attitude of those intellectuals, this paper examines the major works produced during this period as it relates to understanding the impact of Averroes' original works during these years $^{20}$ :

15 Encyclopedia Judaica, Second edition, Vol 2, 724.

16 Maḥfūz, A., «introduction to the edition», in al-Ğābirī, M. Ā., Kitāb al-Kulliyyāt fì al-țib; ma 'a mu 'jam fí al-muștalahāt al-țibiyya al- 'arabiyya [The Book of Generalities of Medicine: With a Glossary of Arabic Medical Terms], Beirut, Markaz Dirāsāt al-Waḥda al-'Arabiyya, 2008, pp. 95-118:107.

17 Steinschneider, M., Die hebräischen Übersetzungen des Mittlelalters und die Juden als Dolmetscher, Berlin, 1893 [repr. Graz 1956], P. 278.

18 Cf. al-Ğābirī, M. Ā., 'Ibn Rushd: sīra wa fikr [Ibn Rushd: biografía y pensamiento], Markaz Dirāsāt al-Wahda al-'Arabiyya, (Beirut, 2001), 67.

19 Cf. al-Ǧābirī, M. Ā., Ibn Rushd: sīra, p. 247.

20 In making this summary, I reviewed several works, mainly; Orfali, M., Biblioteca de autores lógicos hispano judíos (siglos XI-XV), Granada, Universidad de Granada, 1997.p.167. Šạlāne A., Ibn Ruš̌d wa al fikr 
Yěda 'yāh ha-Benīnī ben Abraham ha-Baderšī (or Bederš̄i): most likely was born in 1280, he lived in Perpignan and Montpellier, and his most famous work was Sĕfer Bĕhinat ha- 'Olam (The Book of the Examination of the World). ${ }^{2 l}$ We do not know much about his life, but he was likely influenced by Christian scholasticism, which began to have a more moderate stance during that time; «that instead of seeing science and faith as irreconcilable parallel entities, it saw science and faith as a unit.» ${ }^{22}$ Steinschneider questions «if the ha-Beninn̄'s criteria is the same as that of Alexander, according to Averroes' Paraphrase; and whether it was he who translated the fragment commented on by Mošeh Narbōn̄i and Yūsěf ben Šem Ṭob. Essentially, it is an epitome of De Anima de Aristóteles.» ${ }^{23}$ Ha-ma' amar be-hafke ha mahalak (Treatise on Opposite Motions) is based on an extract from the Long and Middle Commentaries of Averroes in his On the Heavens. He also made commentaries on some parts of Moreh Nébukim (Guide for the Perplexed).

Qalōnymūs ben Qalōnymūs: He had great influence on the intellectual culture in southern France, where he was known as Master Calo. He was born in Arles in 1287, studied in Salonde-Provence and participated in several translations in Rome, which he visited between 1318 -1322. He later returned to Arles, where he settled ${ }^{24}$. Between 1313-1317, he translated several commentaries of Averroes, including The topics, the Sophistici Elenchi and Posterior Analytics. He experienced the difficult living situation of southern France during those times. This can be noted in his form of writing, as his tone frequently turns melancholic. For example, in his Even Bohan, he talks explicitly about the events of the year $1322 .{ }^{25} \mathrm{He}$ also translated the letter of the Brothers of Human Purity about animals ('Iggeret Ba'alei Hayyim), and he says that it is very different from Kalīla wa dimna and other types of stories because it contains many moral meanings that serve as condolence and solace. ${ }^{26}$ In fact, this letter is a radical criticism of Abbasid society. The animals complain of the injustice of human beings before the King of the Genies. Animals represent good while humans represent evil. Domestic animals have some evil characteristics that come from their familiarity with humans. What interests us most is that this treatise discusses the relationship between the governor, the people

al 'ibry al wașiț, Marrakesh, al Maṭba'a wa al-Waraqa al-Wațaniyya, 1999. Renan, E., Averroes y el Averroismo (Ensayo histórico), Madrid, Libros Hiperión, 1992. Cruz Hernández,M., Abū-l-walīd Ibn Rušd (Averroes): Vida, obra, pensamiento, influencia, Córdoba, Publicaciones del Monte de Piedad y Caja de Ahorros de Córdoba, 1986. In addition, to complete the information about some authors or translators I added information from other sources, such as Steinschneider, M., Die hebräischen Übersetzungen. Ramón Guerrero, R., «La transmisón a Europa de Averroes ». In Ayala Martínez, J.M., (ed.), Averroes y los averroísmos, Zaragoza, Actas del III Congreso Nacional de Filosofía Medieval, 1999. Jewish Enciclopedia. Zonta, M., «Influence of Arabic and Islamic Philosophy on Judaic Thought, » The Stanford Encyclopedia of Philosophy (Spring2011Edition), Edward N .Zalta (Ed.). Lomba Fuentes, J., EL Ebro: Puente de Europa: pensamiento musulmán y judio, Zaragoza, Mira Editores, 2002. Lomba Fuentes, J., La raíz semítica de lo europeo, Madrid, Ediciónes Akal, 1997. A. Chahlane, «Averroes, Maimónides, y la crisis en la comunidad judía medieval», Anales del Seminario de Historia de la Filosofia, Vol. 22,2005, pp.111-123. La Encyclopaedia Judaica.

21 Rudavsky, T.M., «The Jewish Tradition: Maimonides (b. 1135; d. 1204), Gersonides (b. 1288 ; d. 1344), and Bederšī (b. 1270; d. 1340) ", in Individuation in Scholasticism: The Later Middle Ages and the Counter-Reformation, 1150-1650, ed. Jorge J. E. GRACIA, Albany, SUNY Press, 1994, pp. 69-96: 86.

22 Maria Paula Britofile, «La Escolástica. De Aristóteles a Santo Tomás a la filosofía moderna», Arte y Práctica, 2012.

23 Steinschneider 1893, citado por Orfali, M., Biblioteca, p. 167.

24 Šạlān, A., Ibn Rushd, p. 505.

25 Ibid., p. 506.

26 Ibid., p. 509.š 
and religion. The governor must be rational and should have all of the good moral characteristics; (rational) governance and religion are Twins, the people must obey.

Sulaymān b. Ibrahim b. Dāūd: translated al-Kulliyyāt fì al-țib in the early $14^{\text {th }}$ Century. We do not have much information about his personal life. Mahrūz says that it is highly probable that he had an unknown version of this book, because it contains some information that is not available in other versions.

Šĕmu'el ben Yěhudah (from Marseille), he was born in 1294, and was arrested with other Jews in the city of Beaucaire in 1321. He moved between Murcia (Spain in 1324), France; Tarascon (1329-1330), Aix du Provence (1335-1336) and Montélimar. Šĕmu'el was one of the Jewish intellectuals who studied philosophy (since the age of 18) and was in conflict with the Rabbis. According to Ramón Guerrero, «he confirmed the existence of an environment of secular speculation, which put into doubt the pretensions of religion of being an absolute authority in controlling people's actions. He did so based on the reading of the Commentary of Plato's Republic and the Middle Commentary of Nicomachean Ethics by Aristotle, works of Averroes and Samuel translated into Hebrew. ${ }^{27}$ In his prologue to Commentary of Plato's Republic, Šĕmu'el provides us with interesting information, first about Jewish knowledge about practical philosophy. He says, «Until today, nothing about this science had been translated nor was there any tradition, neither from the Philosopher nor others, except for the content in the Treatise on the Principles of Beings by Abū Nasr al-Fārābī. This book reached the hands of our people; however, it was only a partial copy, with just a portion of the second part about this science and nothing from the first part. $\rangle^{28}$ As a good scholar of philosophy, Šĕmu'el knows that this science consists of two parts: the first is ethics, the second is politics. Averroes translated the first part, the Middle Commentary on Nicomachaen Ethics, in 117677. When he did not find the second part of Aristotle, he then commented on Plato's Republic. Šĕmu'el says, "When I did this translation, I had not seen Averroes' Commentary on Aristotle's Ethics, which forms the first part of this practical science. I had just seen the same text of the philosopher, and I was incapable of translating it due to its complexity and difficulty. I completely dedicated myself to it with great effort, until the master Averroes' Commentary of this part finally fell into my hands. It was written in a clear and distinct language, as he normally writes in his commentaries. I began to translate it, by the mercy of God, I gave it my full effort and intention to translate Plato's Republic, which completes the political science, correcting the errors as best as I could. $\rangle^{29}$ Also interesting is his description of the situation faced by Jewish intellectuals during those years. After complaining of health problems and the problems he faced with the translation from Arabic, he said: «I decided to attempt the translation of this practical science with the aid of the Christian scholars, but it was impossible to do so, due to the threat of expulsion or imprisonment that was imposed on us by this nation.» ${ }^{30}$

Rabbī Leví ben Gerršon (Gersonides), was born in Bagnols-sur-Cèze in 1288 and died in 1344. He lived in Avignon and Orange and made commentaries on Averroes' works. He was a follower of Averroes, even maintaining a critical spirit and a personal point of view. He

27 Ramón Guerrero, R., «La transmisón», P. 113.

28 Averroes, Exposición, pp. 153-154.

29 Ibid., pp. 151-152.

30 Averroes, Exposición, p. 154. 
adopted the theory of the double truth ${ }^{31}$ and subscribed to an extreme Aristotelian position. His most famous philosophical work is Milhamōt Adōnay (Wars of the Lord) in which he discusses theological and metaphysical problems that according to him, Maimonides left unresolved. He attempts to develop Maimonides' system, starting from a foundation set by Averroes, criticizing Maimonides and in particular, attacking his Neoplatonic ideas. Orfali says that Averroes «was for his own philosophy what Al-Fārābī and Avicenna were for Maimonides school of thought. $\gg{ }^{32}$ It should be said that this work was the basis of his Biblical commentaries. Gersonides had great influence on Jewish thought. It is «worth noting that debates on questions of interpretation of the writings of Ibn Rushd were frequent in 'the school of Levi'..> ${ }^{33}$ He fomented philosophical studies, and along with his disciples, Jews started producing a series of super-commentaries on Averroes' commentaries. They explain and interpret Averroes' commentaries, and in some cases change and 'correct' them. ${ }^{34}$ Some considered him the precursor to Spinoza. In his Middle Commentary on Organon, he criticized Averroes and took an independent stance. Despite his views, his «super-commentaries are the best instrument for interpreting Averroes. $\rangle^{35} \mathrm{He}$ made his commentaries about the final books of the Organon, in 1323. That is, nearly ten years after the translations by Qalōnymūs ben Qalōnymūs.

Yūsĕf Kaspi was born in 1270 in Bonafoux d'Argentiere, France. He lived in Arles, Tarascon, Aragon, Cataluña, Mallorca and in 1314, he traveled to Egypt. He died in Tarasconin 1340. He was the author of many works, and in general, he followed Aristotle and Averroes. In his work, there is a concern for «reconciling philosophy and faith, or for finding the middle path between them.» ${ }^{36}$ In his Zěrōr ha-Kěsĕf (Bundle of Silver), he uses the translation by Y. Anatoli of Averroes' Middle Commentaries. In his work, Těrūmat Kěsĕf (Oblation of Silver) he uses the translation by Samuel of Marseilles about Averroes' aforementioned commentaries: Aristotle's Ethics and Plato's Republic. Kaspi made commentaries with political concerns, declaring the return of the Jewish population to Israel and the construction of the Jewish state. Kaspi makes his summary nine years after Samuel's translation.

Qalōnymūs b. David b. Todros, from Arles, translator of Tahäfut al-tahäfut. In the introduction of the translation, it seems as though the conflict with the anti-philosophy school of thought was still present in Provence. Perhaps because of these conflicts and in order to avoid the danger implied with translating one of Averroes' philosophical works, he excuses

31 For Averroes, there is only one truth, but it has two aspects, reason and faith, which lead to the same truth: «the words revealed by God are taken to be true and assuming that with them we are invited to philosophical reasoning that leads to searching for the truth, it is positively clear to all of us, that is, for Muslims, that philosophical reasoning will not lead us contrary to what is contained in the divine revelation, because the truth cannot contradict the truth, but be in harmony with it and serve as a conformational testimony». Averroes, «Fașl al-maqāl» [Decisive doctrine about the fundamental concordance between the revelation and science], in Alonso, M., Teología de Averroes, Sevilla, 1998, pp. 149-200: 161.

32 Orfali, M., Biblioteca, p. 173.

33 Glasner, R., «Levi ben Gershom and the study of Ibn Rushd in the fourteenth century», The Jewish Quarterly Review, 1995, pp. 51-90.

34 Cf. Harvey, S., «De Maimónides a Crescas», in Targarona Borrás, J., Sáenz-Badillos, A. \& Izquierdo Benito, R. (Coord.), Pensamiento y mística hispanojudia y sefardí, Colección Humanidades, $\mathrm{n}^{\circ}$ 62, Cuenca, Ed de la Universidad de Castilla-La Mancha, 2001 [ X Curso de Cultura Hispanojudía y Sefardí de la Universidad de Castilla-La Mancha], pp. 125-144.

35 Orfali, M., Biblioteca, p. 177.

36 Ibid., P. 169. 
himself for translating the book of «a heretic» by saying he was pushed by friends to translate it into Hebrew. He says he only translated it because it contained the work of al-Gazāli ${ }^{37}$ who defended religion. He said that if he had found the work of al- Gazālī, he wouldn't have translated Averroes' work, ${ }^{38}$ even though there was already a translation by Isaac, and another started by Qalōnymūs ben Qalōnymūs, ${ }^{39}$ as mentioned earlier. This last translation was from Arabic into Latin at the behest of King Robert I of Naples, completed in the same year as the Hebrew translation in 1328. This shows the awareness of the need to translate this work. King Robert was known as «the wise one» ${ }^{40}$ and was also called «the pacifier of Italy.» ${ }^{41}$ Bringing peace was the main objective that both the Christian King and the Jewish translator b. Todros shared. Calō Qalōnymūs is another Jewish translator of the same work from Hebrew into Latin (in 1527). He knew Averroes' works very well. He referred to some of Averroes' works, underlining their importance for understanding and explaining Averroes' commentaries. He said:

Calo Calonymos hebraeus illustri Domino Alberto pio Carpensium Domino. S. P. D. Averroes expositorum princeps, Excellens Domine, in pluribus Arist. Philosophiae voluminibus et logicis et physicis et metaphysicis et moralibus tria genera commentariorum, magna scilicet commentaria, paraphrases et epithomata in diversis suis etatibus edidit. Nec destitit in senectute multos et multos edere libellos et epistolas in quibus quidem se castigavit in multis quaesitis de his quae in praedictis commentariis dixerat ac se clarius elucidat, si deminute in eis se gesserat. Que omnia fere volumina apud hebreos reperiuntur et correcta quidem non autem corrupta, ut plurima que apud latinos, ex quibus perfecte mens Averrois ad mentem Arist. In omnibus suis operibus iam dictis elicitur. ${ }^{42}$

Țodros ben Měšullām ben David, of Arles, was born in 1314, and he lived in Trinquetaille. His signature may be significant in understanding the difficult situation experienced by Jewish

37 Šạlān questions this excuse and finds that it is true that Averroes' book contains everything that alGazali said in a very sincere and loyal manner, but then Šahlān asks if he did not have al- Ġazālī’s book Tahāfut al falāsifa, how did he know that Averroes' book contained everything that al- Ġazālī had written in that book (cf, Šahlān, A., Ibn Rushd, P. 512.

38 Averroes, Or Abul Walid Muhammed Ibn Ahmad Ibn Roshd, jewishencyclopedia.com, available at: http://www.jewishencyclopedia.com/articles/8012-ibn-roshd.

39 Gottheil, R. \& Broydé, I., Qalōnymūs Ben David Ben Ṭodros, jewishencyclopedia.com, available at:

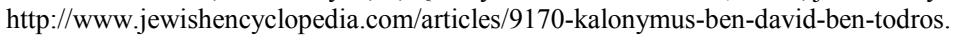

40 Najemy, J. M., Italy in the Age of the Renaissance 1300-1550, New York, Oxford University Press, 2005 , p. 225. 62.

41 Lancaster, J., In the Shadow of Vesuvius: A Cultural History of Naples, IB Tauris, (London, 2005),

42 Calō Qalōnymūs, «Libellus seu espistola Averrois de connexione intellectu abstracti cum homine, nuperrime traductus ab eximio doctore Calo Calonymos hebreo neapoltano Venetiis comorante ». was published next «Libellus de mundi creatione » on p. 111 ss. Work not consulted, cited by Alonso, M., Teología, p. 101:[Calō Qalōnymūs, Jew, wishes good health to Lord Alberto Pío, príncipe de Carpi, (salutem plurimam dicit): Venerable Lord: Averroes, prince of the commentators, published at different times in his life three types of commentaries (great commentaries, to be sure), paraphrase, and epitomes in many of the volumes of Aristotle's Philosophy, both about logic, physics, metaphysics and morality. In his later years, he did not stop publishing more and more books and letters, in which he corrected many of the questions that he had stated in the previous commentaries, and in them he writes clearly and lucidly what he had previously discussed only briefly. Nearly all of these volumes are with the Jews and in correct, not corrupt versions, and many among the Latin-speakers, in which Averroes' mind is perfectly transferred to Aristotle's mind, as was mentioned in all of his works.] 
intellectuals during that time. His signature reads «Todoros Todorosi descendent of the Jews» and the dates are written, followed by «of the history of the Jews.» This may indicate that he had been forced to convert to Christianity. ${ }^{43} \mathrm{He}$ translated the appendix of al- Damima, which was included in the work Fașl. In al-Damima, Averroes explains the question of God's knowledge of particulars. It was based on Aristotle distinguishing between the knowledge of God and the knowledge of man. He said «the mistake in this matter has arisen simply from making an analogy between the eternal knowledge and originated knowledge i.e., between the suprasensible and the sensible; and the falsity of this analogy is well known. $\rangle^{44}$

Mošeh Narbōnī was born in the late $13^{\text {th }}$ or early $14^{\text {th }}$ Century in Narbonne, France. He lived in Barcelona, Toledo, Burgos and Soria. In his work, Ma 'amar be-efšarut ha-débequt (Treatise about the possibility of conjunction), he followed Averroes' philosophy. Later he wrote a commentary on the Guide for the Perplexed (he completed it in 1362 in Soria). He also wrote a commentary on Maqāṣid al-Falāsifa by al-Ghazalii ${ }^{45}$, and Hayy ibn Yaqzān by Ibn Țufayl. He also produced a series of super-commentaries on Averroes' commentaries. He wrote an epistle called 'Iggeret 'al Si 'ür Qömah (Epistle on Shiur Qomah), which shows his concern for reconciling philosophy and the Kabbalah. He follows Averroes and criticizes Maimonides in some cases.

The philosopher and Kabbalist Yūsěf ibn Waqar lived in Toledo in the $14^{\text {th }}$ Century and was sent to Granada on a diplomatic mission. He wrote a Kabbalist treatise, Sefer ha-yihüd (Book of the unity). He tried to reconcile philosophy and astrology with the Torah and specifically the Kabbalah. He wrote al-maqāla al-ğàmi 'a bayna al-falsafa wa al-šarī'a (The reconciliation of philosophy and religious law). He thinks that «by means of a dialectic, a correlation can be established between astrology, philosophy and the Kabbalah. ${ }^{46}{ }^{46}$ was influenced by several Muslim authors, including al- Ġazālī. ${ }^{47}$ Maimonides and Averroes were

43 Šahlān, A., Ibn Rushd, pp. 517-518.

44 I used the English translation of this part as mentioned in Druart, T. A., «Averroes on God's Knowledge of Being Qua Being», Anaquel de estudios árabes, (5), 1994, pp. 39-58.

45 Harvey noted that in addition to Narboni's school, the text was copied and studied in several schools, including the school of Abraham Bibago, and was commented on by several scholars, including; Yișhāq ben Šem Ṭob Harvey asks why these Jews returned to this book by al-Ghazali in the 14th Century, even though they already had translations of the Averroes' commentary of Aristotle, and it was not largely popular until the 15 th Century. The reason for this is that in the 14th Century, the text had several translations and was unable to convince the philosophers and religious thinkers. The Averroists, like al- Balag and al-Narbōn̄i, used him like a trampoline to teach Averroes' science. However, in the 15th Century, it is possible that Hasday Crescas was the first Jew to study this work (in Hebrew translations). In it, he saw an alternative to Averroes' science. Henceforth, the book was studied as a scientific text. cf. Harvey, S., «Why Did Fourteenth-Century Jews Turn to Al-Ġāālī's Account of Natural Science? », The Jewish Quarterly Review, Vol. 91, No. 3/4, Jan- Apr, 2001, 359-376: 375-6.

46 Orfali, M., Biblioteca, p. 139.

47 Al-Ġazālī wrote at the service of Niẓām al-Mulk, who adopted the ahsharism as an official ideology of the Seleucid state. The arch enemies of al-Mulk were the ismā îlíes, who eventually killed him. Al- Gazālī attacked the philosophers, and the bātiníes, mu'tazila and the ismā'īlíes, and of course, Avicenna who concurs with them. It must be said that during al- Ġazālī’s life, he changed his opinion frequently, and there are many "contradictions" in his books (depending on the reader to which it is directed), according to the Andalusian Ibn Țufayl: «It connects in one place and disconnects in another, it anaesthetizes certain doctrines, which he later professes himself.» [«The Self-Taught Philospher», translation by Angel González Palencia, p.18. Cited by Martínez Lorca, A., «La filosofía en al-Andalus: una aproximación histórica», In Martínez Lorca, A. (coord.), Ensayos sobre la filosofia andalusí. Barcelona, Anthropos, 1990)]. Averroes, a friend of Ibn Țufayl, said «and the proof that with it he wanted to awaken the spirits is that he did not adopt a determined doctrine in his books, 
his main sources in logic. He only knows Aristotle's work through the works of Averroes. Avicenna, Al-Fārābī and Ibn Țufayl also influenced him ${ }^{48}$.

Yishāq ben Šem Ṭob (first half of the $15^{\text {th }}$ Century), son of a Kabbalist and anti-rationalist. His father, Šem Ṭob iben Šem Ṭoḅ, wrote a book attacking the Jewish rationalists, but Yiṣhāq was a loyal rationalist to the Stagirite. ${ }^{49} \mathrm{He}$ taught philosophy in Aguilar de Campo and among his conserved works, there is a super-commentary on Averroes' Middle Commentary on Aristotle's Physics and a commentary in favor of Morěh Nébukim.

Yūsěf ben Šem Ṭob (died in 1480), was born in Medina del Campo de Leon, Castilla (1441), Alcalá de Henares (1451), Segovia (1454) $)^{50}$. Older brother of Yiṣhāq. He was a defender of philosophy and was influenced by Averroes. He wrote two commentaries on Averroes, one shorter and one longer, about the Epistle of the possibility of conjunction. Averroes' influence is very clear because he wrote short and long commentaries on Aristotle's work. In Mozne ha-'Tyyūn, he attempts to show that there is no contradiction between philosophy and faith.

Šem Ṭ̂b ben Yūsěf ben Šem Ṭoḅ, son of Yūsěf ben Šem Ṭob. Rabbī, philosopher and preacher (15 $5^{\text {th }}$ Century). He lived in Segovia and Almazán. He attempted to reconcile reason and faith, was a defender of Aristotelianism and Maimonides. He made super-commentaries on Averroes' Middle Commentaries on Physics and On the Soul by Aristotle. He also wrote a commentary about the Morĕh Nébukim. It is worth mentioning that this commentary was widely distributed during the Middle Ages. It accompanied most editions of Morěh Něbukim. It was used by scholars of Maimonides.

Abraham Bibago (circa 1446-1489) lived in Huesca. He made a commentary on Averroes' Middle Commentary on Metaphysics. His thought influenced Yiṣhāq 'Aramāh and Yiṣhāq Abravanĕl.

Yiṣhāq 'Aramāh (circa 1420-1494), lived in Zamora (possibly his birthplace), Tarragona, Fraga (Aragon), Catalayud, and after the expulsion, he went to Naples where he eventually died. He was a Talmudist and philosopher, Castilian Rabbi, who was influenced by Maimonides thought and the Aristotelianism. He criticized some Averroists for being in discord with the laws of the Torah, according to him. He wanted to show everything that came from Aristotle is in the Torah in a more perfect way. In his work Sĕfer Hazut Qašĕh, he tries to show that philosophy depends on theology.

Abraham Šalōm (died in 1492), we do not know much about his life, but we have information that he lived in Cervera. He translated a work of Albert Magnus from Latin into Hebrew Ha-pilōsōfyah ha-Tibbe'it. He attempts to reconcile reason and faith. He was a defender of Maimonides and demonstrates impressive knowledge about Averroes. ${ }^{51}$ He wrote

nor did he adhere to any specific school; when among the ash 'aryys, an ash aryy; when among the Sufis, a Sufi, and when among the philosophers, a philosopher. Even to the extent that one can say about him, as the poet said: One day you are Yemeni, if you encounter someone from Yemen, just as if you encounter a Mu'addi, you will be a Mu'addi» (Averroes, «Fașl al-maqāl”, p. 149-200:186). Perhaps this voluble character, al- Gazālī, is what allowed the Jews in the 14th and 15th Centuries to find what they were looking for, according to the interests of the seeker. Cf. Chahlane, A., «Averroes, Maimónides».

48 Orfali, M., Biblioteca, p. 139.

49 Ibid., p. 188.

50 Jacobs, J. \& Schloessinger, M., Ibn Shem-Tob, Joseph Ben Shemtob, JewishEncyclopedia.com, available at: http://www.jewishencyclopedia.com/articles/8019-ibn-shem-tob-joseph-ben-shemtob

51 Cf. Orfali, M., Biblioteca, p. 200. 
Neweh Šalom (The Indwelling of Peace). When he finds that Maimonides' opinions are not adapted to religion, he says that the affirmations from Maimonides should not be taken word for word.

Ěli Habillo (second half of the $15^{\text {th }}$ Century), he lived in Monzon and Aragon. He influenced Christian scholasticism and translated philosophical works from Latin into Hebrew, including several works by Thomas Aquinas. He wrote several commentaries to the Incoherence of Philosophers by al-Ġazālī, to the Middle Commentary of Organon by Averroes and a compendium of the Milhamōt Adōnay by Gersonides.

Elías del Medigo (1450-1493), considered to be the last great Jewish Averroist, he was a professor in Padua, and the master of Mirandola. He commented on several works by Averroes. ${ }^{52}$ Regarding his Examination of religion, Hernandez says that he «reproduces the arguments of Fașl al-maqāl, which says that philosophy is the best and most legitimate path for men to reach truth, coinciding in its essence with the teaching revealed by God and enclosed in Scripture. When discord appears between both, it must be recognized, because both paths may not coincide, though that happens very seldom.. ${ }^{53}$

\section{DISCUSSION AND CONCLUSIONS}

The Jewish Averroists translated the works of al-Ġazālī at nearly the same time as they translated Averroes' original works. For the majority, reconciling philosophy and religion was a fundamental question. From the late $13^{\text {th }}$ Century ${ }^{54}$ and through the $14^{\text {th }}$ Century, they looked for a new, less confrontational method, by translating Maqasid al-Falasifa by al-Ghazali and the original works of Averroes. We find intellectuals from different tendencies who looked for the wise man who harmonized rationality and religion. We find Qalōnymūs b. David b. Todros, who clearly defends religion and thinkers like al-Ġazālī, translating Averroes. Like him, in the $15^{\text {th }}$ Century, we find other people closely linked to the Scripture or the Kabbalah, translating or commenting on Averroes. Moises Orfali says «Yūsěf along with his son Šem Tọ ben Yūsěf and Yiṣhāq 'Aramāh represent the school of Hispano-Jewish thinkers influenced by the Kabbalah. The philosophy of Yūsĕf ibn Šem Țob seeks a compromise between Aristotelian-Maimonidean rationalism and the anti-philosophical tendency that his father represented.» ${ }^{55}$

Regarding the location where these intellectuals carried out activities, during the $14^{\text {th }}$ Century, southern France was the epicentre, specifically Provence. After the expulsion of the Jews from the French kingdom in 1394, the center of intellectual activities moved from Provence to northern Spain (see Table). With respect to Averroes' original works, we find the translations of two of them ${ }^{56}$ : one philosophical work, Tahäfut al-tahäfut (Incoherence of the Incoherence), and one religious work, Damìma li-mas 'alat al-'ilm al-qadìm (Letter to a friend

52 Encyclopaedia judaica, second edition, Vol 2, 724.

53 Cruz Hernández, M., Abv̄-l-walīd, p. 302.

54 Al-Balag is a Jewish Averroist from the 13th Century, and was very loyal to Averroes. He translated Maqāṣid al-Falāsifa de Algazel, (circa 1292) with the following argument: «Translating this book seemed like a wise idea because it collects the majority of doctrines, following a method and criteria that harmonizes philosophy and faith. » (Isaac al-BALAĠ, Sëfer tikun ha-deÿot. ed. VAJDA, G., (Israel, 733[1973]). Work not consulted, cited by Chahlane, «Averroes, Maimonides»).

55 Orfali, M., Biblioteca, p. 191.

56 The translators of the other two works are unknown. 
about the Science of God). There was also the translation of his political agenda in his Commentary of Plato's Republic. Furthermore, Gersonides was also in Provence. He opened the door to producing super-commentaries on Averroes' commentaries. Among these intellectuals, it seems as though there was a trend of making conciliations in order to escape the tumultuous situation to which they arrived after clashes between the rationalists and antirationalists. In Averroes' original works, they found the alternatives to the problems that emerged between Aristotelian ideas and religious law. In the Commentaries, Averroes gave his opinion when he finds that Aristotle's ideas are in discord with those of the revelation, commenting and completing Aristotle's ideas (when he did not address the problem), according to "what his doctrine establishes.» Yet in his original works he dedicates his full effort to solving these problems, but always in a way that does not contradict the revelation; In Faṣl al-maqāl ${ }^{57}$, Averroes' main question was whether the law allows the study of philosophy. His solution was the understanding of philosophy and religion as two separated domains; they are two ways, but both of them lead to truth, the same truth. This was his answer to the clash between reason and faith. In this premise. Elias del Medigo built his arguments on this solution, because of the vulnerable situation of philosophy and the philosopher he attempted to give them more autonomy. ${ }^{58}$ Yūsĕf Kaspi was an author concerned for the delicate situation that Jewish communities were experiencing at that time. He planned the return to the Holy Land and the establishment of a Jewish state. He summarized Averroes' Commentary of Plato's Republic. Averroes' commentary was written in similar situation. At that time, Averroes saw that politics in his land led the community to a divisive situation. He harshly criticized «politics that made one single society into several» and he presented in this work his reformist political project where he confirms that philosophy is necessary to make a correct interpretation of the law and thus the application of politics and the construction of the state. ${ }^{59}$ Narboni took a big interest in the passage "On natural science" at the end of al-Tahafut. He uses it in his commentary on the Moreh Nebukim, and he uses it again in his supercommentary on Averroes' work. The following text shows how he moves between different texts, introducing an argument from Tahäfut to explain, or 'to illuminate' a problematic question in the commentary on Metaphysics XII;

Here you see that lbn Rushd explained that Plato thought that some of these proportions and psychic powers created in the elements were Forms, and that they were the principles and matices for the forms of compounds. Thus, I quoted for you what I quoted of lbn Rushd 's discourse at the end of Tahāfut al Tahāfut, about the souls which are the generators for the forms in compounds, or are themselves suspended in bodies which they generated according to the likeness which is between them; and [in the latter case] when the bodies are corrupted, they return to their spiritual matter and subtle, individual, celestial bodies which cannot be perceived. And the truth of Ibn Rushd's discourse is when he said that all the ancient philosophers acknowledged these souls, for truly it is an ancient doctrine. And how very wonderfully it agrees with God's words...I have been lengthy in bringing forward the words of lbn Rushd to illuminate this question; and in as much as we have seen that $\mathrm{He}$ who directs our particular species to the human

57 We must take into account that both Kašf and Faṣl were not known by intellectuals that read in Latin.

58 C,f. Popkin, R. H., The Pimlico history of Western philosophy, Random House, 2011.

59 C,f. Guerrero, R., «Legislador y poder en la filosofía política del Islam y del Judaísmo», In Roche, P ., (coord.), El pensamiento político en la Edad Media, Madrid, Editorial Centro de Estudios Ramón Areces, 2010, pp. 191-213: 203. 
entelechy in this, our Exile, has transmitted to us words that agree with his opinion, let us break off the discussion about this, and return to our commentary on the words of this treatise. $^{60}$

In short, not like their antecedents from the thirteen century, in the fourteenth and fifteenth centuries, both rationalists and Kabbalists were interested in Averroes original works because they both looked for a compromise between Aristotelian-Maimonidian rationalism and the anti-philosophy tendency. A precise comparative study is needed of these commentaries, on the Guide for the Perplexed and the super-commentaries on Averroes' commentaries. However, in the meantime, we can assume the following: Jews in the $14^{\text {th }}$ and $15^{\text {th }}$ Centuries used the original works to complete or change the «errors» or «misunderstandings» that emerged in the earlier translations of Averroes' commentaries on Aristotle (due to their ignorance of the original works, at that time, as noted by Calō Calōnymūs), and in this way they were able to produce super-commentaries. They also used them to write commentaries on the same book of Maimonides that caused all of the clashes that led to the division of the Jewish community. They comment on it guided by the alternatives that Averroes offers in his original works. Finally, they used them to do new readings of the Scriptures.

ACKNOWLEDGMENT: I would like to express my deepest gratitude to Prof. María Dolores Ferre Cano for making the realization of this study possible.

Table. Works influenced by Averroes' school of thought or translations of his works

\begin{tabular}{|c|c|c|}
\hline Work & $\begin{array}{l}\text { Authors } \\
\text { (A)/Translators (T) }\end{array}$ & Date \\
\hline $\begin{array}{l}\text { - Ha-De 'ot ba-Šsekel ha- } \\
\text { hōmrī (Theories of the } \\
\text { Material Intellect) }\end{array}$ & \multirow{3}{*}{$\begin{array}{l}\text { Yěda'yāh ha-Benīnī } \\
\text { ben Abraham ha } \\
\text { Baderšī or Baderšī } \\
\text { (A) }\end{array}$} & $\begin{array}{l}\text { Late } 13^{\text {th }} \\
\text { and early } \\
14^{\text {th }}\end{array}$ \\
\hline $\begin{array}{l}\text { - Ha-ma 'amar be-hafke ha } \\
\text { mahalak (Treatise on } \\
\text { Opposite Motions) }\end{array}$ & & Century \\
\hline $\begin{array}{l}\text { - Commentary to parts of } \\
\text { Morěh Něbukim }\end{array}$ & & \\
\hline Faṣl al-maqāl & (T) & $\begin{array}{l}\text { Late } 13^{\text {th }} \\
\text { or early } \\
14^{\text {th }} \\
\text { Century }\end{array}$ \\
\hline
\end{tabular}

60 Cited in Goldstein, H. T., «Dator Formarum: Ibn Rushd, Levi ben Gerson, and Moses b. Joshua of Narbonne», In Al-Faruqi, I. R., Essays in Islamic and Comparative Studies, Washington, International Institute of Islamic Thought, 1982, pp. 107-121. 


\section{Tahäfut al-tahäfut (Sĕfer Isaac (T) First half ha-Teqūmah) \\ of the $14^{\text {th }}$ \\ Century}

He translated several works of the commentaries of Averroes;

- The Topics

- The Sophistic Arguments

- Secondary Analytics

- Generation and Corruption

- The Meteors

- Physics

- Metaphysics

al-Kulliyyāt fĩ al-ṭibb

\section{Commentary on Plato's Republic}

Commentary on

Nicomachean Ethics
Qalōnymūs b. Qalōnymūs of Arles (T)
1313-1317 Arles (born)

Salon-de-Provence

Rome (1318-1322)

\section{Sulaymān $b . \quad$ Early $14^{\text {th }}$ Ibrahim b. Dāūd} (T)

Šĕmu'el ben

Yěhudah

Marseilles) (T)

1320

$1321-$

revised in

1322

Murcia (1324)

Tarascon-Provence

(1329-1330)

Aix-Provence (1335-

1336)

Montélimar

Rabbī Leví ben

Gěršon

(Gersónides) (A)
1321-1324 Bagnols-sur-Cèze (born: 1288)

Avignon-Provence

Orange-Provence

Physics, Generation and Corruption, Meteors, On the Soul and others.

- Milhamot Adonay (Wars of the Lord) 
- Zěrōr ha-Kĕsĕf (Bundle of Silver)

- Tĕrūmat Kĕsĕf (Oblation of Silver)

Tahāfut al-tahāfut (Happalat ha-Happalah)

- al-Damìma

- Middle Commentary on Rhetoric and Poetics.

- Ma'amar be-efśarut hadébequt (Treatise about the Possibility of Conjunction)

- A commentary on the Guide for the Perplexed

- Commentaries on Maqāṣid al-Falāsifa by al-Ġazālī, and Hayy Ibn Yaqzān by Ibn Țufayl

- Super-commentaries on Averroes's commentaries - 'Iggeret 'al Si 'ūr Qōmah (Epistle on Shiur Qomah)

\section{al-kašf 'an manāhiğ al- adilla}

- al-maqāla al-ğami ‘ a bayna al-falsafa wa al-šarī'a (Reconciliation of philosophy and religious law).

-Sĕfer ha-yihūd (Book of the unity)

\section{$\underline{\text { Yūsĕf Kaspi (A) }}$}

First half of the $14^{\text {th }}$

Century

Qalōnymūs b.

David b. Todros

(T)

\section{Ṭodros ben \\ Měšullām ben \\ David (T)}
Mošeh Narbōnī (A) - Late $13^{\text {th }}$ or early $14^{\text {th }}$ Century$$
\text { Century }
$$
completed in 1362 1337 1337

1328

\section{Anonymous (T)}

Yūsěf ibn Waqar (A)

\section{Post-1350}

Bonafoux Largentière (born: 1270) Arles, Tarasconin, Aragón, Cataluña, Mallorca

Arles (born)

Provence

Arles (born: 1314)

Trinquetaille - Arles

Narbonne (born)

Barcelona, Toledo, Burgos, Soria.

$\begin{array}{ll}14^{\text {th }} & \text { Toledo } \\ \text { Century } & \text { Granada }\end{array}$


Super-commentary to Averroes' Middle

Commentary on Aristotle's Physics and a Commentary in favor of The Guide for the Perplexed.

A super-commentary about Averroes' Paraphrase of Aphrodisia's work On the Intellect. He later added a commentary to Morěh Nébukim, and another to Mošeh Narbōnī and Averroes On the Epistle of the Conjunction, and later about Aristotle's vision of the intellect according to Averroes' commentary of On the Soul. He also wrote Mozne ha-'Iyyūn.

- Super commentaries to Averroes Middle Commentary of Physics and De Anima by Aristotle.

- A Commentary on Morěh Něbukikim

\section{al-Damīma}

A super-commentary on Averroes' Middle

Commentary on Metaphysics.

Sefer Hazut Qašěh

Neweh Šalom (The Indwelling of Peace)
Yiṣhāq ben Šem Ṭob (A)

First half of the $15^{\text {th }}$

Century

Yūsěf Ben Šem Ṭob

(A)

First half of the $15^{\text {th }}$ Century

Castilla (born), Medina del Campo de Leon (1441), Alcalá de Henares (1451), Segovia (1454)
Šem Țob ben Yūsěf ben Šem Ṭob (A)

\section{Anonymous (T)}

Abraham Bibago (A)

Yiṣhāaq 'Aramāh

Abraham Šalōm
Second half of the $15^{\text {th }}$

Century

\section{Segovia, Almazan}

\section{2}

$15^{\text {th }}$

Huesca

Century

Second
half of the
$15^{\text {th }}$

Zamora, Tarragona, Fraga (Aragon),

Century Calatayud, Naples

Second Cervera
half of the
$15^{\text {th }}$
Century


- Be'ur Kvanot ha-pilōsōfim sel al-Gazālī le Maestre

Manoel (Commentary to the Intentions of Philosophers by al-Giazāì)

- Be'ur al ha-Be'ur ha-Emsa isel

Ibn Rushd le/Sifre

ha/Higayyon sel Aristo

(Super-commentary on

Averroes' Middle

Commentary of Organon by

Averroes).

- He commented on several of Averroes' works

- Examination of religion
Ěli Habillo (A)

Second

half of the

$15^{\text {th }}$

Century
Elias del Medigo

(A) $15^{\text {th }}$

Century
Monzon, Aragon 